\title{
Testing Whether Camera Presence Influences Habitat Specific Predation Pressure on Artificial Shorebird Nests in the Arctic
}

\author{
Kevin G. Young, ${ }^{1,2}$ Lisa V. Kennedy, ${ }^{3}$ Paul A. Smith ${ }^{4}$ and Erica Nol ${ }^{1,3}$
}

(Received 21 June 2018; accepted in revised form 6 August 2020)

\begin{abstract}
When monitoring the breeding ecology of birds, the causes and times of nest failure can be difficult to determine. Cameras placed near nests allow for accurate monitoring of nest fate, but their presence may increase the risk of predation by attracting predators, leading to biased results. The relative influence of cameras on nest predation risk may also depend on habitat because predator numbers or behaviour can change in response to the availability or accessibility of nests. We evaluated the impact of camera presence on the predation rate of artificial nests placed within mesic tundra habitats used by Arctic-breeding shorebirds. We deployed 94 artificial nests, half with cameras and half without, during the shorebird-nesting season of 2015 in the East Bay Migratory Bird Sanctuary, Nunavut. Artificial nests were distributed evenly across sedge meadow and supratidal habitats typically used by nesting shorebirds. We used the Cox proportional hazards model to assess differential nest survival in relation to camera presence, habitat type, placement date, and all potential interactions. Artificial nests with cameras did not experience higher predation risk than those without cameras. Predation risk of artificial nests was related to an interaction between habitat type and placement date. Nests deployed in sedge meadows and in supratidal habitats later in the season were subject to a higher risk of predation than those deployed in supratidal habitats early in the season. These differences in predation risk are likely driven by the foraging behaviour of Arctic fox (Vulpes lagopus), a species that accounted for $81 \%$ of observed predation events in this study. Arctic fox prey primarily on Arvicoline prey and goose eggs at this site and take shorebird nests opportunistically, perhaps more often later in the season when their preferred prey becomes scarcer. This study demonstrates that, at this site, cameras used for nest monitoring do not influence predation risk. Evaluating the impact of cameras on predation risk is critical prior to their use, as individual study areas may differ in terms of predator species and behaviour.
\end{abstract}

Key words: nest survival; cameras; Arctic shorebirds; artificial nests; predation risk; Cox proportional hazard

RÉSUMÉ. Lors de la surveillance de l'écologie de reproduction des oiseaux, les causes et les périodes de défaillance des nids peuvent être difficiles à déterminer. Des caméras placées près des nids permettent une surveillance précise du sort des nids, mais leur présence peut augmenter le risque de prédation en attirant les prédateurs, ce qui entraine des résultats biaisés. L'influence relative des caméras sur le risque de prédation des nids peut également dépendre de l'habitat, car le nombre ou le comportement des prédateurs peut changer en fonction de la disponibilité ou de l'accessibilité des nids. Nous avons évalué l'impact de la présence de caméras sur le taux de prédation des nids artificiels placés dans les habitats de la toundra mésique utilisés par les limicoles se reproduisant dans l'Arctique. Nous avons installé 94 nids artificiels, la moitié avec des caméras et l'autre moitié sans caméras, pendant la saison de nidification des limicoles de 2015 dans le Refuge d'oiseaux migrateurs de la baie Est, au Nunavut. Les nids artificiels étaient répartis uniformément dans les cariçaies et les habitats supratidaux généralement utilisés par les limicoles nicheurs. Nous avons utilisé le modèle à risques proportionnels de Cox pour évaluer la survie différentielle des nids en fonction de la présence de caméras, du type d'habitat, de la date d'installation des caméras et de toutes les interactions potentielles. Les nids artificiels équipés de caméras ne présentaient pas de risque de prédation plus élevé que ceux sans caméras. Le risque de prédation des nids artificiels était lié à une interaction entre le type d'habitat et la date d'installation des caméras. Plus tard dans la saison, les nids placés dans les cariçaies et dans les habitats supratidaux ont fait l'objet d'un risque de prédation plus élevé que ceux des habitats supratidaux en début de saison. Ces différences de risque de prédation sont probablement attribuables au comportement d'alimentation du renard arctique (Vulpes lagopus), une espèce qui représentait $81 \%$ des événements de prédation observés dans cette étude. Le renard arctique se nourrit principalement d'arvicolinés et d'œufs d'oie sur ce site, et s'empare des nids de limicoles de manière opportuniste, peut-être plus souvent plus tard dans la saison, lorsque ses proies préférées se font plus rares. Cette étude démontre que, sur ce site, les caméras servant à la surveillance des nids n'influencent pas le risque de prédation. Il est essentiel d'évaluer l'impact des caméras sur le risque

\footnotetext{
${ }^{1}$ Department of Biology, Trent University, Peterborough, Ontario K9L 0G2, Canada

${ }^{2}$ Corresponding author; current address: Department of Biology, Advanced Facility for Avian Research, Western University,

London, Ontario N6A 5B7, Canada; kyoun24@uwo.ca

${ }^{3}$ Environment and Life Sciences Graduate Program, Trent University, Peterborough, Ontario K9L 0G2, Canada

${ }^{4}$ Wildlife Research Division, Environment and Climate Change Canada, Ottawa, Ontario K1S 5B6, Canada

(C) The Arctic Institute of North America
} 
de prédation avant leur utilisation, car chacune des zones étudiées peut différer sur le plan des espèces de prédateurs et des comportements.

Mots clés : survie du nid; caméra; limicole de l'Arctique; nids artificiels; risque de prédation; modèle à risques proportionnels de Cox

Révisé pour la revue Arctic par Nicole Giguère.

\section{INTRODUCTION}

Cameras are a commonly used tool for monitoring the nests of breeding birds as they can provide information about nest attendance and provisioning behaviours, parental defense, nest fate, and the identity of nest predators and their foraging behaviours (Ball and Bayne, 2012; Ribic et al., 2012; Brautigam et al., 2016; Ellis et al., 2018). Cameras can be an efficient supplement or replacement for direct human observation (Ribic et al., 2012). However, when a novel object like a camera (or other conspicuous marker) is placed near a nest, it can influence the behaviour of predators by either attracting them to the nest location (Reynolds, 1985; Renfrew and Ribic, 2003) or dissuading them (Herranz et al., 2002; Richardson et al., 2009). Cameras can also potentially affect incubation behaviour of the monitored birds in similar ways, and birds have abandoned their nests following placement of a camera (Brown et al., 1998; Renfrew and Ribic, 2003; Liebezeit, 2013). The value of cameras as a research tool is in part dependent on whether they effect changes in predator behaviours, reproductive success, or parental behaviour.

Previous studies on the survival of artificial or real shorebird nests in association with camera presence have reported either no differences (Liebezeit and Zack, 2008; McKinnon and Bêty, 2009), reduced (Liebezeit, 2013), and greater survival probability (Bentzen et al., 2017). Conflicting results among studies on the influence of cameras on shorebird nest survival may be caused by differences in methodology or predator-prey dynamics at local scales. Differences among studies in methodology and study sites justify the continued evaluation of cameras as an appropriate tool to monitor shorebird nests in diverse habitat conditions given the potential influence cameras may have on nest survival and subsequently the results of studies that use them (i.e., a potential observer effect) (McKinnon and Bêty, 2009). Predation is the primary cause of nest failure for most birds (Ricklefs, 1969; Martin, 1993) and Arctic-breeding shorebird nests are especially vulnerable to predation from both Arctic fox (Vulpes lagopus) and Parasitic Jaegers (Stercorarius parasiticus). In particular, the Arctic fox is the most common predator of shorebird nests, especially during years of low lemming abundance (Liebezeit and Zack, 2008; McKinnon et al., 2013; Flemming et al., 2019a). The predation rate of shorebird nests with cameras may depend on the foraging efforts of Arctic fox within different habitats, in addition to the relative availability of primary prey items within different habitat types (i.e., lemmings: Dicrostonyx and
Lemmus spp., or goose eggs: Anser, Chen, and Branta spp.). Shorebird nest predation rates vary throughout the short breeding period of shorebirds (Smith and Wilson, 2010; Liebezeit et al., 2011) and across habitats (Smith et al., 2007). Both avian and mammalian predators must provide food for their developing offspring and hunt with increasing intensity as their offspring age, which may cause predation pressure on shorebird nests to increase as the breeding season progresses (Gilg et al., 2006; McKinnon et al., 2013). Arctic foxes are opportunistic specialist predators that prefer Arvicoline prey (Elmhagen et al., 2000). Foraging efforts of Arctic fox may be concentrated in areas where preferred prey such as collared lemmings (Dicrostonyx groenlandicus) and nesting waterfowl are found (Stickney, 1991; Samelius et al., 2007). Arvicoline rodents are not commonly found in areas near the coast with saline conditions (Banfield, 1974), and predator search efforts might be lower in these habitats. As a result of this foraging habitat preference, Arctic fox may be more likely to encounter and depredate shorebird nests within sedge meadow than in habitats that provide fewer prey items. If camera presence is used as a cue to find nests, cameras may have greater influence on nests in habitats that are not subject to intense predator foraging efforts. By contrast, nests in areas already subject to intense foraging efforts may not experience a similar increase in predation pressure. Additionally, using cameras as a cue to find shorebird nests may be a learned response by predators (Reynolds, 1985), and therefore the effect of cameras on nest survival may be greatest later in the breeding season or in years following the use of cameras at nests.

Predation rates on shorebird nests are influenced by both the habitat features of the nest itself (e.g., concealment) and the behaviour of the nesting bird(s), including both incubation and nest defense behaviours (Smith and Wilson, 2010; Smith et al., 2010, 2012). In the Arctic, where the diversity of nest predators is low, artificial nests offer a useful alternative to real nests for controlled experiments in measuring relative predation risk (McKinnon et al., 2010a; Bentzen et al., 2017). Artificial nests cannot accurately mimic the presence of adult shorebirds but may be effective proxies for assessing relative predation risk of real nests in designed experiments when the predator communities that prey upon each are similar (Pärt and Wretenberg, 2002; McKinnon et al., 2010b).

Here, we use artificial nests to evaluate whether camera presence influences the relative predation risk of shorebird nests at an Arctic breeding site. We predicted that camera presence would not influence artificial nest depredation 
rates in our study area because they have been successfully deployed without an enhancement of nest predation in another similar Arctic study site (McKinnon et al., 2010a). Because visual concealment could have an important influence on nest survival, we compared concealment measures of real and artificial nests to determine how closely our artificial nests mimicked the concealment of real shorebird nests. Finally, we tested for the influence of interactions between nest placement date, habitat type, and camera presence, to ensure that spatial and temporal variability in predation rates of artificial nests did not obscure the effects of cameras and to assess differences in predation risk across the study site and season.

\section{METHODS}

\section{Study Site}

Our study was conducted from 3-27 July 2015, at the East Bay Migratory Bird Sanctuary, Southampton Island,

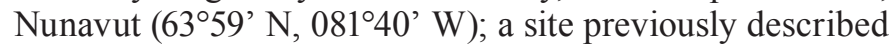
by Smith and Wilson (2010). The study site is composed of diverse tundra habitats: low-lying areas near the coast are characterized by sparse vegetation, rocky substrate, and many brackish ponds. Farther inland, habitat diversity increases with low-lying moss, sedge, and grass areas, drier habitats dominated by ericaceous shrubs and forbs, and gravel ridges with sparse vegetation (Smith et al., 2007; Smith and Wilson, 2010). Five shorebird species commonly nest at the study site: Red Phalarope (Phalaropus fulicarius), White-rumped Sandpiper (Calidris fuscicollis), Ruddy Turnstone (Arenaria interpres), Semipalmated Plover (Charadrius semipalmatus) and Black-bellied Plover (Pluvialis squatarola).

\section{Artificial Nests}

We placed a total of 94 artificial nests across the study area, with 48 nests placed in sedge meadow habitats and 46 in areas influenced by saline conditions near the coast (hereafter "supratidal") (Fig. 1). While these areas have a saline influence from salt spray, they are all well above the high-tide mark. Sedge meadows are characterized by moss-covered peat, abundant graminoid vegetation, and small hummocks while supratidal habitat is characterized by sand and rock substrate, with sparse patches of heavily goose-grazed Puccinellia spp. (Smith et al., 2007). We placed cameras at half of the nests in each habitat. Artificial nests consisted of four Japanese quail (Coturnix japonica) eggs placed uncovered on the ground without added nest lining, in a divot resembling a shallow nest scrape just large enough to accommodate the eggs $(<10 \mathrm{~cm}$ diameter). A nail with a small piece $\left(0.5 \mathrm{~cm}^{2}\right)$ of brightly coloured flagging tape was driven into the substrate and hidden beneath the eggs to allow relocation of the nest following predation events. Artificial nests were placed a minimum of

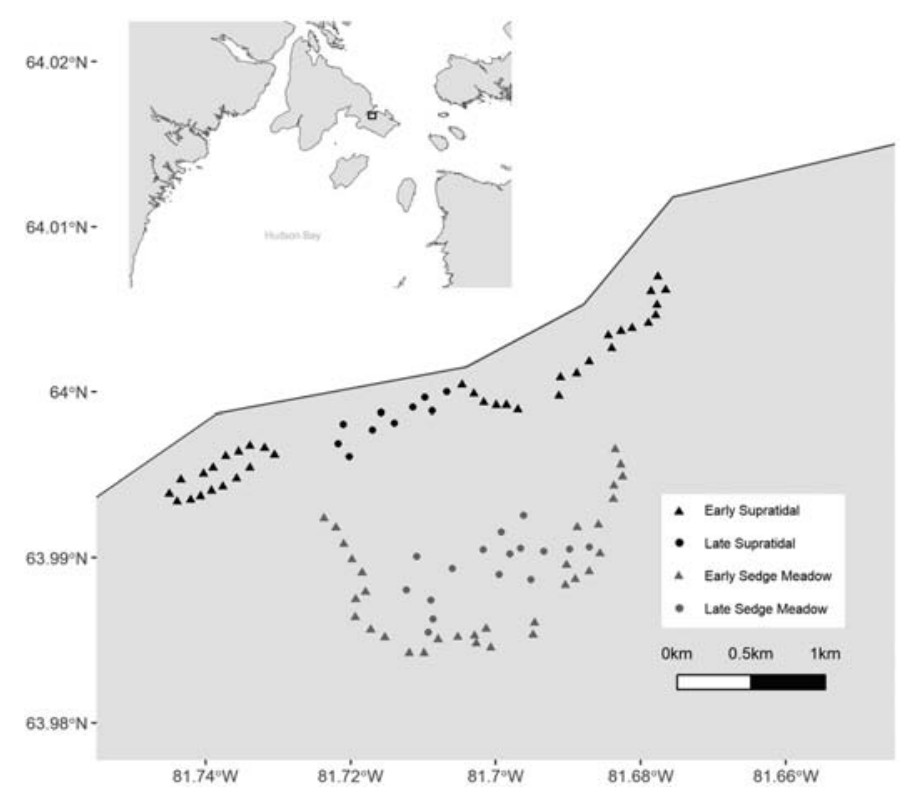

FIG. 1. Distribution of artificial nests placed in sedge meadow and supratidal habitat, and both early and late in the season within the study area at the East Bay Migratory Bird Sanctuary, Southampton Island, Nunavut.

$70 \mathrm{~m}$ from all other (known) real or artificial nests initiated during the breeding season. When placing artificial nests, we selected locations that were similar to those selected by shorebirds at this site. Sedge meadow habitats in East Bay have short vegetative cover $(\sim 5 \mathrm{~cm})$ and low hummock heights $(\sim 10 \mathrm{~cm})$. Within sedge meadow habitats, site characteristics used by nesting shorebirds and chosen by us included relatively high vegetation and locations on or near hummocks. In supratidal habitat, both real and artificial nests were placed on dry, silty substrate between the rocks that cover much of the area.

Within each habitat type, Day 6 Outdoors Plotwatcher ProTM trail cameras were placed at half of the artificial nests. Cameras were placed approximately $10 \mathrm{~m}$ from the nests, at a random bearing from the nest, and set on camouflage-painted stands (Fig. 2) with a total height of $50 \mathrm{~cm}$. Cameras were set to take continuous 24-hour timelapse videos by capturing one photo every $5 \mathrm{sec}$. Following their placement, we checked artificial nests once every two days until failure or to 22 days (a typical incubation duration for shorebirds at this site), at which point the nest would be considered successful. We identified nest predators by watching videos and observing photos that contained predators with eggs in their mouths or with their head at the nest location on the nest failure date.

We placed nests in both sedge meadow and supratidal habitats throughout the period from 3-19 July 2015. As older nests were depredated and cameras became available, new nests were constructed and cameras were moved. When cameras were available, we deployed new nests evenly distributed between habitats and camera treatments on each date. Nests placed from 3-11 July were considered "early" and nests placed from 13-19 July were considered "late" nests. In sedge meadow habitat, we constructed 16 


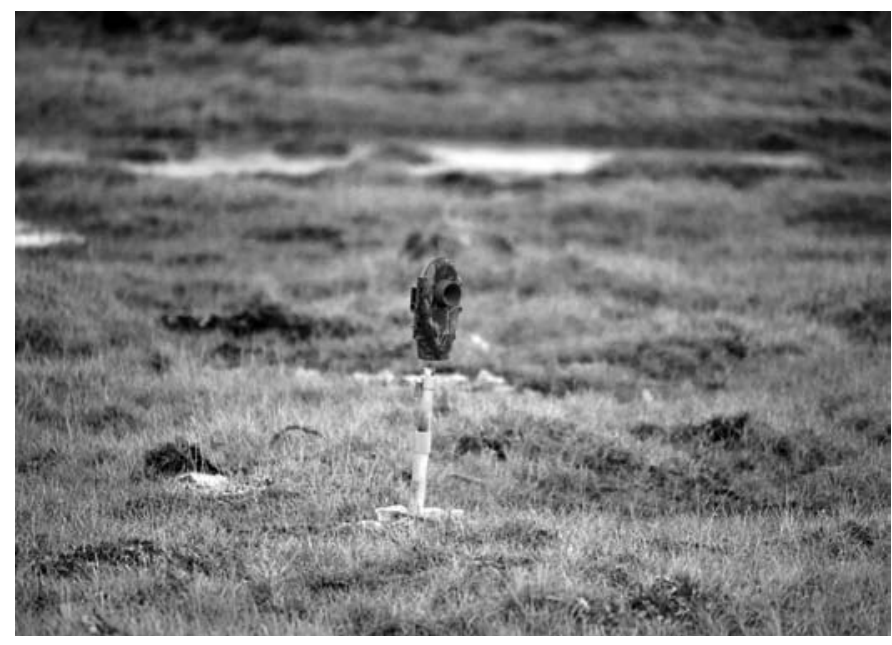

FIG. 2. A Day 6 Plotwatcher ProTM camera deployed on Southampton Island. Rocks are placed on the wooden stand to stabilize the camera in high winds. Cameras were placed $10 \mathrm{~m}$ from nests and the total height is approximately $50 \mathrm{~cm}$.

and 32 nests in the early and late periods, respectively. In supratidal habitat we constructed a total of 10 artificial early nests and 36 late nests.

\section{Concealment}

Microhabitat characteristics around shorebird-nesting sites can provide visual concealment from predators. White-rumped Sandpipers and Red Phalaropes construct nest scrapes with high concealment while the other species that nested within our study area rely on early detection of predators, with nests with little vegetative cover (Smith et al., 2007, Flemming et al., 2019b). We used three, $12 \mathrm{~cm}$ diameter disks, marked with a grid system and fastened together at right angles to create an identical silhouette in four directions and from above (Smith et al., 2007). Nest concealment was measured by placing the disk into a nest cup, observing the disks from a distance of $4 \mathrm{~m}$ and $40 \mathrm{~cm}$ above the ground (mimicking the observation height of the Arctic fox) from each cardinal direction and directly above the nest, and estimating the percentage of the disks' grid system covered by the vegetation, rocks, or hummocks surrounding the nest cup.

\section{Statistical Analysis}

Cox proportional hazard regression was used to determine whether camera presence, habitat type, or date of nest deployment was related to the survival time for artificial nests (Cox, 1972; Fox, 2001). We selected Cox proportional hazard regression because it is a semiparametric method for estimating hazard ratios without assuming a baseline hazard function. This method also allows for right censoring (i.e., unknown fate of individuals surviving beyond the end of the study). The Cox model is appropriate here because nests were placed across multiple days and some nests survived to the end of this study. The initial model contained camera presence, habitat type, and placement date with all possible interactions. Nonsignificant factors were removed until the final model was reached. The Cox model assumes that the hazard ratio is proportional to the survival function (i.e., differences in survival probability are proportional among groups across time). We assessed this assumption statistically and graphically using Schoenfeld residuals analysis (Fox, 2002). Survival estimates were generated from the fit Cox model following Laine and Reyes (2014). We compared concealment of artificial and real nests located within sedge meadow and supratidal habitats using an independent $\mathrm{t}$-test. All statistical analyses were conducted in $\mathrm{R}$ version 3.2.2. The Cox proportional hazard model and figures were created using the "Survival" and "ggplot2" packages respectively (Therneau, 2015; Wickham, 2016; R Core Team, 2017).

\section{RESULTS}

Most of the artificial nests failed within two days $(71.7 \%)$, and none (with or without cameras) survived beyond 14 days. Time-lapse footage from the 47 nests with cameras captured 43 predation events; four predation events were missed by the cameras. Arctic foxes were by far the most common predator of artificial nests (81\%), with Herring Gulls (Larus argentatus) and Parasitic Jaegers accounting for $14 \%$ and $5 \%$ of recorded predation events, respectively (Table 1).

The proportional hazards assumption was met for all variables included in the model $(p>0.05)$, which indicates that survival probability was proportional among treatment groups (camera presence, placement date, and habitat). The model was also assessed for and satisfied the general linear model assumptions of influential values (i.e., individual points driving measured relationships) and non-linearity (i.e., residuals fit a normal distribution) graphically (Fox, 2002). Camera presence had no effect on the failure rate of artificial nests $(\mathrm{z}=1.17, p=0.24, \beta=0.80, \mathrm{CI}=-0.53,2.13$; Fig. 3). The interaction between habitat type and initiation

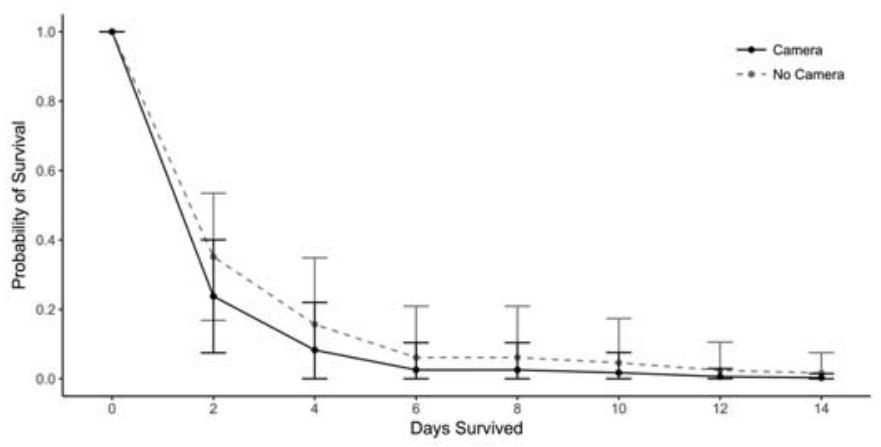

FIG. 3. Survival estimates $( \pm \mathrm{SD})$ of artificial nests placed with (solid line) and without (dotted line) cameras associated, as estimated by Cox proportional hazard regression. The probability of survival is estimated at 2-d intervals coinciding with nest checks. 
TABLE 1. Number of artificial nests depredated by each of three predator species, within sedge meadow and supratidal habitats at East Bay, Southampton Island, Nunavut, in July 2015. Predators were identified from camera footage at nests.

\begin{tabular}{lccr}
\hline \hline Predator & Sedge meadow & Supratidal & \multicolumn{1}{c}{ Total } \\
\hline Arctic fox & 15 & 19 & $35(81 \%)$ \\
Parasitic Jaeger & 2 & 0 & $2(5 \%)$ \\
Herring Gull & 5 & 1 & $6(14 \%)$ \\
Total & 22 & 20 & $43(100 \%)$ \\
\hline \hline
\end{tabular}

date was a significant predictor of failure rate $(\mathrm{z}=-3.30$, $p<0.001, \beta=-0.15, \mathrm{CI}=-0.24,-0.06$ ). Nests placed both early and late in July within sedge meadow habitat had similarly low survival estimates (Figs. 4, 1). Nests placed early in July within supratidal habitat had higher survival estimates while nests placed later within supratidal habitats had lower survival estimates, comparable to the survival estimates for sedge meadow nests (Fig. 4). Real shorebird nests were more concealed than artificial nests within supratidal ( $t=3.61, p<0.001$; real (mean $\pm \mathrm{SD}$ ): $17 \pm 3.4 \%$, $\mathrm{n}=11$; artificial: $5 \pm 2.5 \%, \mathrm{n}=46)$ and sedge meadow $(t=4.46, p<0.0001$; real (mean $\pm \mathrm{SD}): 25 \pm 4.2 \%, \mathrm{n}=25$; artificial: $14 \pm 2.1 \%, \mathrm{n}=48$ ) habitats.

\section{DISCUSSION}

We did not detect an effect of camera presence on the survival of artificial nests. Despite the relatively conspicuous appearance of cameras placed on the tundra, their association with artificial nests did not affect the rate that nests were depredated. Thus, common shorebird nest predators such as Arctic fox apparently did not use cameras as cues to locate shorebird nests. Artificial nest survival was, however, dependent on placement date and the habitat in which nests were located.

Artificial nests placed in sedge meadow habitat experienced lower survival than those placed in supratidal habitats regardless of the date. Survival of artificial nests in supratidal habitat was dependent on the date they were set; nests placed early in July survived longer than those placed later. The differential survival of nests based on habitat and initiation date likely reflects the foraging efforts of Arctic fox at the study site, the most commonly identified predator of real and artificial shorebird nests at this site and others (Liebezeit and Zack, 2008; McKinnon and Bêty, 2009). Lemmings are the primary prey item of Arctic fox, and foraging efforts of Arctic fox are more concentrated in sedge meadow where lemmings occur than in supratidal habitat where lemmings are generally absent (Lecomte et al., 2008). Because of this higher foraging effort, foxes probably encounter incidental prey such as artificial nests more frequently in sedge meadow habitat.

By contrast, foxes avoid habitats where numerous ponds make travel difficult for them (Lecomte et al., 2008). The supratidal habitats at East Bay are dominated by ponds.

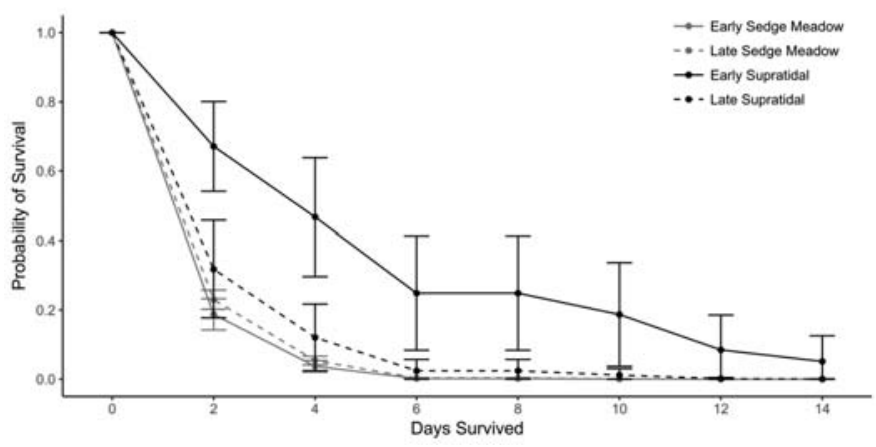

FIG. 4. Survival estimates ( \pm SD) of artificial nests placed within sedge meadow and supratidal habitat stratified by date, as estimated by Cox proportional hazard regression. Survival estimates for nests placed on 3, 7, 9, and 11 July 2015 are "early" nests. Survival estimates for nests placed on 13, 15, 17, and 19 July 2015 are "late" nests.

Despite their ability to swim, Arctic foxes avoid deepwater bodies while foraging (Strub, 1992; pers. observ.) and this standing water early in the season may inhibit or deter Arctic fox from extensive foraging in supratidal habitat. However, as the summer progresses, the ponds evaporate, increasing land connectivity. These drier conditions provide greater access to alternative prey for Arctic fox, including Brant (Branta bernicla) and Cackling Goose (Branta hutchinsii) nests (Peterson, 1990; Anthony et al., 1991). If foxes redirect foraging efforts to supratidal habitats later in the season, the probability that shorebird nests would be incidentally discovered would increase. Furthermore, progression of the breeding season is accompanied by increased energetic demands for all reproductively active adult predators as they must provide food for their offspring (McKinnon et al., 2013). Predator incursions into secondary foraging areas may also be driven by the increased energetic demands of parental care and the associated increase in foraging effort. Increased foraging efforts by Arctic fox in secondary habitats like supratidal areas may be especially important if feeding success on their primary prey (Arvicoline rodents) is low in the sedge meadow habitats.

This study necessarily assumes that artificial nests are a useful proxy for real nests when determining predation risk. Real shorebird nests are simple scrapes in the substrate and thus can be simulated more easily than passerine nests. The artificial nests used in this study were less concealed than real shorebird nests at the same site. Greater visual exposure of nests to predators may have resulted in elevated rates of predation in artificial nests. Predation rates of artificial nests are expected to be further elevated because artificial nests lack the benefit of parental defense behaviours (Nguyen et al., 2006). However, lack of parental activity at the artificial nests could provide fewer cues to nest predators at these nests than at real nests. Importantly, artificial nests cannot be used as proxies for measuring absolute real nest survival but they are effective for measuring relative predation risk, especially in habitats with relatively simple predator communities (Pärt and Wretenberg, 2002). Our results indicate that cameramonitored and control (no camera) artificial nests did not 
differ in their survival; this pattern of no relative survival difference could apply to real nests. However, we cannot rule out that parental defense behaviours either alone or influenced directly by camera presence interact to influence predation of real nests.

Most artificial nests in the present study were depredated by Arctic fox, which is consistent with previously reported observations at this study site of predators on shorebird nests (Smith and Wilson, 2010). Both Herring Gulls and Parasitic Jaegers depredated nests in sedge meadow, but only one nest was taken by a Herring Gull in supratidal habitats (Table 1). Herring Gulls have not been documented as an important predator of real shorebird nests at this site (Smith et al., 2012) and the nest predation events recorded here may not be independent. Based on the camera evidence, five of the six predation events by Herring Gulls occurred within $3 \mathrm{~d}$, and $0.9 \mathrm{~km}$ of each other; these predation events may be attributed to a single individual and thus increased the estimate of avian predation overall and in sedge meadow habitat (Table 1). Despite the possible inflation of Herring Gull predation events, the artificial nest predator guild closely corresponds to that of real nests at this study site (Smith and Wilson, 2010).

Our study was conducted during a year of low lemming abundance and low shorebird nest success (pers. observ.). Smith et al. (2007) found that shorebirds experienced increased nest mortality during a year of low lemming abundance, likely due to Arctic fox foraging for bird eggs when their primary prey was not available. Because of their increased reliance on alternative prey during this study, we expected that nest predators would be more sensitive to cues like cameras that may improve foraging efficiency during years of low primary prey abundance than during years when primary prey are abundant. Artificial nest survival was very low in our study and nearly three-quarter of nests we placed were depredated within two days. It is possible that the rapid predation of artificial nests could have limited our ability to detect an influence of camera presence on survival because of low exposure time. However, given that differences in survival between habitats and placement date were detected, it is unlikely that we failed to detect an influence of camera presence on artificial nest survival in our study.

The present study examined the effect of cameras on predation risk for artificial nests of Arctic-breeding shorebirds. We have shown that the risk of predation for artificial nests varied across two Arctic coastal habitats and across the breeding season in our study year with a higher risk of predation in sedge meadow throughout the breeding season. We cannot eliminate the possibility that this pattern could shift among years depending on the relative availability of prey and the predator responses to prey. While real nest survival was not assessed in this study, artificial nests can be effective proxies of real nests for measuring relative predation risk and we did not find a difference in risk associated with camera presence (McKinnon et al., 2010b). This study provides support for the continued use of cameras as a monitoring tool at this site. Our results also highlight that differences in study site and design may influence results (Bentzen et al., 2017). We recommend that future use of cameras at other study sites be preceded by pilot studies such as the present one to determine any influence of cameras on predator behaviour that could influence predation rate of real nests.

\section{ACKNOWLEDGMENTS}

We thank J. Nakoolak, J. Angootealuk, V. Putinski, G. Holmes, B. Norman, and K. Roper for their assistance in the field. We also thank the community of Coral Harbour, Nunavut, for their assistance. This research was supported by Environment and Climate Change Canada, the Arctic Goose Joint Venture, the Northern Scientific Training Program, Trent University, and logistic support was provided by the Polar Continental Shelf Program.

\section{REFERENCES}

Anthony, R.M., Flint, P.L., and Sedinger, J.S. 1991. Arctic fox removal improves nest success of Black Brant. Wildlife Society Bulletin 19(2):176-184.

Ball, J.R., and Bayne, E.M. 2012. Using video monitoring to assess the accuracy of nest fate and nest productivity estimates by field observation. The Auk 129(3):438-448.

https://doi.org/10.1525/auk.2012.11224

Banfield, A.W.F. 1974. The mammals of Canada. Toronto, Ontario: University of Toronto Press.

Bentzen, R., Dinsmore, S., Liebezeit, J., Robards, M., Streever, B., and Zack, S. 2017. Assessing development impacts on Arctic nesting birds using real and artificial nests. Polar Biology 40(8):1527- 1536 . https://doi.org/10.1007/s00300-017-2074-7

Brautigam, K.J., Osborne, D.C., and White, D. 2016. Photographic evidence and chronology of nest parasitism by a Wild Turkey (Meleagris gallopavo). The Wilson Journal of Ornithology 128(1):204-207. https://doi.org/10.1676/1559-4491-128.1.204

Brown, K.P., Moller, H., Innes, J., and Jansen, P. 1998. Identifying predators at nests of small birds in a New Zealand forest. Ibis 140(2):274-279. https://doi.org/10.1111/j.1474-919X.1998.tb04389.x

Cox, D.R. 1972. Regression models and life-tables. Journal of the Royal Statistical Society: Series B (Methodological) 34(2):187-220. https://doi.org/10.1111/j.2517-6161.1972.tb00899.x

Ellis, K.S., Cavitt, J.F., Larsen, R.T., and Koons, D.N. 2018. Using remote cameras to validate estimates of nest fate in shorebirds. Ibis 160(3):681-687. https://doi.org/10.1111/ibi.12607

Elmhagen, B., Tannerfeldt, M., Verucci, P., and Angerbjörn, A. 2000. The Arctic fox (Alopex lagopus): An opportunistic specialist. Journal of Zoology 251(2):139-149. https://doi.org/10.1111/j.1469-7998.2000.tb00599.x 
Flemming, S.A., Nol, E., Kennedy, L.V., Bédard, A., Giroux, M.-A., and Smith, P.A. 2019a. Spatio-temporal responses of predators to hyperabundant geese affect risk of predation for sympatric-nesting species. PLoS ONE 14(8): e0221727. https://doi.org/10.1371/journal.pone.0221727

Flemming, S.A., Nol, E., Kennedy, L.V., and Smith, P.A. 2019 b. Hyperabundant herbivores limit habitat availability and influence nest site selection of Arctic-breeding birds. Journal of Applied Ecology 56(4):976-987.

https://doi.org/10.1111/1365-2664.13336

Fox, G.A. 2001. Failure time analysis: Studying times-toevents and rates at which events occur. In: Scheiner, S.M., and Gurevitch, J., eds. Design and analysis of ecological experiments. New York: Oxford University Press. 235-266.

Fox, J. 2008. Cox proportional-hazards regression for survival data. Appendix in: Fox, J., An R and S-PLUS companion to applied regression. Thousand Oaks, California: Sage Publications Inc.

https://socialsciences.mcmaster.ca/jfox/Books/Companion-1E/ appendix-cox- regression.pdf

Gilg, O., Sittler, B., Sabard, B., Hurstel, A., Sané, R., Delattre, P., and Hanski, I. 2006. Functional and numerical responses of four lemming predators in high Arctic Greenland. Oikos 113(2):193-216. https://doi.org/10.1111/j.2006.0030-1299.14125.x

Herranz, J., Yanes, M., and Suárez, F. 2002. Does photomonitoring affect nest predation? Journal of Field Ornithology 73(1):97-101. https://doi.org/10.1648/0273-8570-73.1.97

Laine, T., and Reyes, E.M. 2014. Tutorial: Survival estimation for Cox regression models with time-varying coefficients using SAS and R. Journal of Statistical Software 61(c1):1-23. https://doi.org/10.18637/jss.v061.c01

Lecomte, N., Careau, V., Gauthier, G., and Giroux, J.-F. 2008. Predator behaviour and predation risk in the heterogeneous Arctic environment. Journal of Animal Ecology 77(3):439-447. https://doi.org/10.1111/j.1365-2656.2008.01354.x

Liebezeit, J.R. 2013. Identification of shorebird and passerine nest predators at a remote site in the Northeast National Petroleum Reserve-Alaska and in the Prudhoe Bay oil field. Unpubl. report Available at the Wildlife Conservation Society, 2300 Southern Blvd., Bronx, New York 10460, USA.

Liebezeit, J.R., and Zack, S. 2008. Point counts underestimate the importance of Arctic foxes as avian nest predators: Evidence from remote video cameras in Arctic Alaskan oil fields. Arctic 61(2):153-161. https://doi.org/10.14430/arctic32

Liebezeit, J.R., White, G.C., and Zack, S. 2011. Breeding ecology of birds at Teshekpuk Lake: A key habitat site on the Arctic Coastal Plain of Alaska. Arctic 64(1):32-44. https://doi.org/10.14430/arctic4078

Martin, T.E. 1993. Nest predation among vegetation layers and habitat types: Revising the dogmas. The American Naturalist 141(6):897-913.

https://doi.org/10.1086/285515
McKinnon, L., and Bêty, J. 2009. Effect of camera monitoring on survival rates of High-Arctic shorebird nests. Journal of Field Ornithology 80(3):280-288.

https://doi.org/10.1111/j.1557-9263.2009.00231.x

McKinnon, L., Smith, P.A., Nol, E., Martin, J.L., Doyle, F.I., Abraham, K.F., Gilchrist, H.G., Morrison, R.I.G., and Bêty, J. 2010a. Lower predation risk for migratory birds at high latitudes. Science 327(5963):326-327.

https://doi.org/10.1126/science.1183010

McKinnon, L., Smith, P.A., Nol, E., Martin, J.L., Doyle, F.I., Abraham, K.F., Gilchrist, H.G., Morrison, R.I.G., and Bêty, J. 2010b. Suitability of artificial nests-response. Science 328(5974):46-47.

https://oi.org/10.1126/science.328.5974.46-b

McKinnon, L., Berteaux, D., Gauthier, G., and Bêty, J. 2013. Predator-mediated interactions between preferred, alternative and incidental prey in the Arctic tundra. Oikos 122(7):1042-1048. https://doi.org/10.1111/j.1600-0706.2012.20708.x

Nguyen, L.P., Abraham, K.F., and Nol, E. 2006. Influence of Arctic Terns on survival of artificial and natural Semipalmated Plover nests. Waterbirds 29(1):100-104. https://doi.org/10.1675/1524-4695(2006)29[100:IOATOS]2.0. $\mathrm{CO} ; 2$

Pärt, T., and Wretenberg, J. 2002. Do artificial nests reveal relative nest predation risk for real nests? Journal of Avian Biology 33(1):39-46. https://doi.org/10.1034/j.1600-048X.2002.330107.x

Peterson, M.R. 1990. Nest-site selection by Emperor Geese and Cackling Canada Geese. The Wilson Bulletin 102(3):413 - 426.

R Core Team. 2017. R: A language and environment for statistical computing. Vienna, Austria: The R Foundation.

Renfrew, R.B., and Ribic, C.A. 2003. Grassland passerine nest predators near pasture edges identified on videotape. The Auk 120(2):371-383.

https://doi.org/10.1642/0004-8038(2003)120[0371:GPNPNP]2. $0 . \mathrm{CO} ; 2$

Reynolds, J.D. 1985. Sandhill Crane use of nest markers as cues for predation. The Wilson Bulletin 97(1):106-108.

Ribic, C.A., Thompson, F.R., and Pietz, P.J., eds. 2012. Video surveillance of nesting birds. Studies in Avian Biology 43. Berkeley and Los Angeles California: University of California Press. https://doi.org/10.1525/9780520954090

Richardson, T.W., Gardali, T., and Jenkins, S.H. 2009. Review and meta-analysis of camera effects on avian nest success. Journal of Wildlife Management 73(2):287-293.

https://doi.org/10.2193/2007-566

Ricklefs, R.E. 1969. An analysis of nesting mortality in birds. Smithsonian Contributions to Zoology 9:1 - 48. https://doi.org/10.5479/si.00810282.9

Samelius, G., Alisauskas, R.T., Hobson, K.A., and Larivière, S. 2007. Prolonging the Arctic pulse: Long-term exploitation of cached eggs by Arctic foxes when lemmings are scarce. Journal of Animal Ecology 76(5):873 -880. https://doi.org/10.1111/j.1365-2656.2007.01278.x 
Smith, P.A., and Wilson, S. 2010. Intraseasonal patterns in shorebird nest survival are related to nest age and defence behaviour. Oecologia 163(3):613-624. https://doi.org/10.1007/s00442-010-1644-y

Smith, P.A., Gilchrist, H.G., and Smith, J.N.M. 2007. Effects of nest habitat, food, and parental behavior on shorebird nest success. The Condor 109(1):15-31. https://doi.org/10.1093/condor/109.1.15

Smith, P.A., Gilchrist, H.G., Forbes, M.R., Martin, J.-L., and Allard, K. 2010. Inter-annual variation in the breeding chronology of Arctic shorebirds: Effects of weather, snow melt and predators. Journal of Avian Biology 41(3):292 - 304. https://doi.org/10.1111/j.1600-048X.2009.04815.x

Smith, P.A., Tulp, I., Schekkerman, H., Gilchrist, H.G., and Forbes, M.R. 2012. Shorebird incubation behaviour and its influence on the risk of nest predation. Animal Behaviour 84(4):835-842.

https://doi.org/10.1016/j.anbehav.2012.07.004
Stickney, A. 1991. Seasonal patterns of prey availability and the foraging behavior of Arctic foxes (Alopex lagopus) in a waterfowl nesting area. Canadian Journal of Zoology 69(11):2853-2859.

https://doi.org/10.1139/z91-402

Strub, H. 1992. Swim by an Arctic fox, Alopex lagopus, in Alexandra Fiord, Ellesmere Island, Northwest Territories. Canadian Field-Naturalist 106(4):513-514.

Therneau, T.M. 2015. A package for survival analysis in R, version 2.38. Vienna, Austria: The R Foundation. https://CRAN.R-project.org/package=survival

Wickham, H. 2016. Data analysis. In: ggplot2: Use R! Cham, Switzerland: Springer.

https://doi.org/10.1007/978-3-319-24277-4_9 